\title{
I calvari salentini. Analisi grafica e documentazione
}

\author{
Gabriele Rossi \\ Francesca Sisci
}

\section{Abstract}

I calvari devozionali rientrano nella tipologia delle cosiddette architetture minori. L'area a sud della Puglia, il Salento, è particolarmente interessata da questo fenomeno nel periodo a cavallo tra il XIX e inizio XX secolo. I promotori e finanziatori di queste opere sono ordini mendicanti e privati cittadini, che in tal modo dotano il loro paese di una 'copia' del sacro monte Calvario: culmine della via crucis e del viaggio dei pellegrini in Terra Santa. L'interesse verso queste architetture nasce in quanto espressione della memoria religiosa di una comunità, ed allo stesso tempo per la loro eterogeneità. Lo studio condotto si pone l'obiettivo di proporre una classificazione geometrico/formale dei calvari; per farlo ci si avvale degli strumenti del rilievo per la loro conoscenza e documentazione, e del disegno per la loro lettura ed analisi grafica. Si è poi condotto uno studio comparativo arrivando così a classificarli secondo delle macro-categorie, e per ognuna di esse individuare le varianti.

Nel presente contributo vengono presentati tre casi studio: Carovigno, Erchie e Melpignano. Ognuno di essi afferisce ad una delle tre macro-categorie individuate, e presenta caratteristiche utili ad una lettura tipologico/formale che contempla il modello di riferimento e la sua conversione in oggetto architettonico.

Parole chiave

calvari, documentazione, rilievo, analisi grafica, Salento.

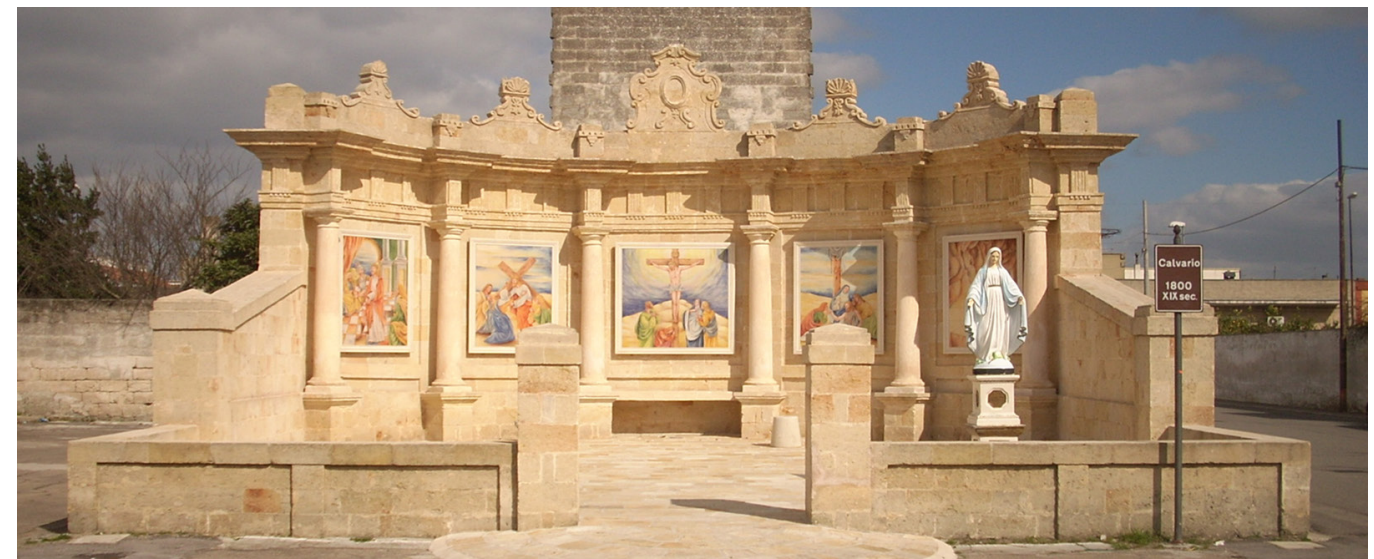




\section{Introduzione}

La pratica devozionale dei pellegrinaggi in Terra Santa si diffonde sin dai primi secoli dell'era cristiana. Essa è ben documentata dai diari dei viaggiatori medievali, in cui vengono raccontate le tappe del percorso compiuto alla volta dei luoghi dove visse e morì Gesù Cristo [Alliata, Bottini, Kaswalder et al. 2009]. Nel 3 I 3 d.C. l'imperatore Costantino accordò ai cristiani la completa libertà di culto con l'Editto di Miliano, rendendo sempre più diffusa l'abitudine al pellegrinaggio, da lui stessa incentivata con la costruzione della Chiesa del Santo Sepolcro. Da allora tale pratica si può definire ininterrotta, infatti anche se tra il VII e il X secolo la navigazione tra Oriente e Occidente divenne difficoltosa, a causa delle conquiste musulmane delle aree balcaniche, il rallentamento del flusso dei pellegrini ebbe come contropartita la creazione di una serie di Santuari che cercavano di riproporre in patria ciò che i pellegrini avrebbero potuto vedere in Terra Santa [Perretti 20 I I]. Lo stesso avvenne durante il periodo delle spedizioni crociate (fine XI e metà XIII secolo) in cui il diffondersi di santuari che riproducevano i Luoghi santi, come le Case di Nazaret, i Sacri Monti o le Gerusalemme traslate, anticipavano la devozione moderna della Via Crucis. L'esito di questa pratica, nata dalla necessità di salvaguardare l'incolumità dei viaggiatoti, contribuì al trasferimento del senso del pellegrinaggio dal piano materiale a quello spirituale.

Alla categoria de luoghi santi appartengono i calvari. Essi nascono e si diffondono a seguito del Concilio di Trento ( 1545 - 1563), che impose una revisione della Passio Christi e la costituzione dell'itinerarium fidei in modo da garantire a tutti i devoti gli stessi doni spirituali accordati ai primi pellegrini medievali.

II termine calvario deriva dal latino calvarium, che in aramaico significa cranio (gulgulta), ovvero la collina fuori delle mura di Gerusalemme sulla quale venne crocifisso Gesù Cristo secondo le Sacre Scritture. Per tale motivo i calvari rappresentano episodi paradigmatici di una devozione popolare che tenta di trasporre nel percorso processionale della via crucis, che si snoda attraverso le aree urbane, e culmina nel raggiungimento del calvario, la singolare esperienza religiosa del pellegrinaggio in Terra Santa.

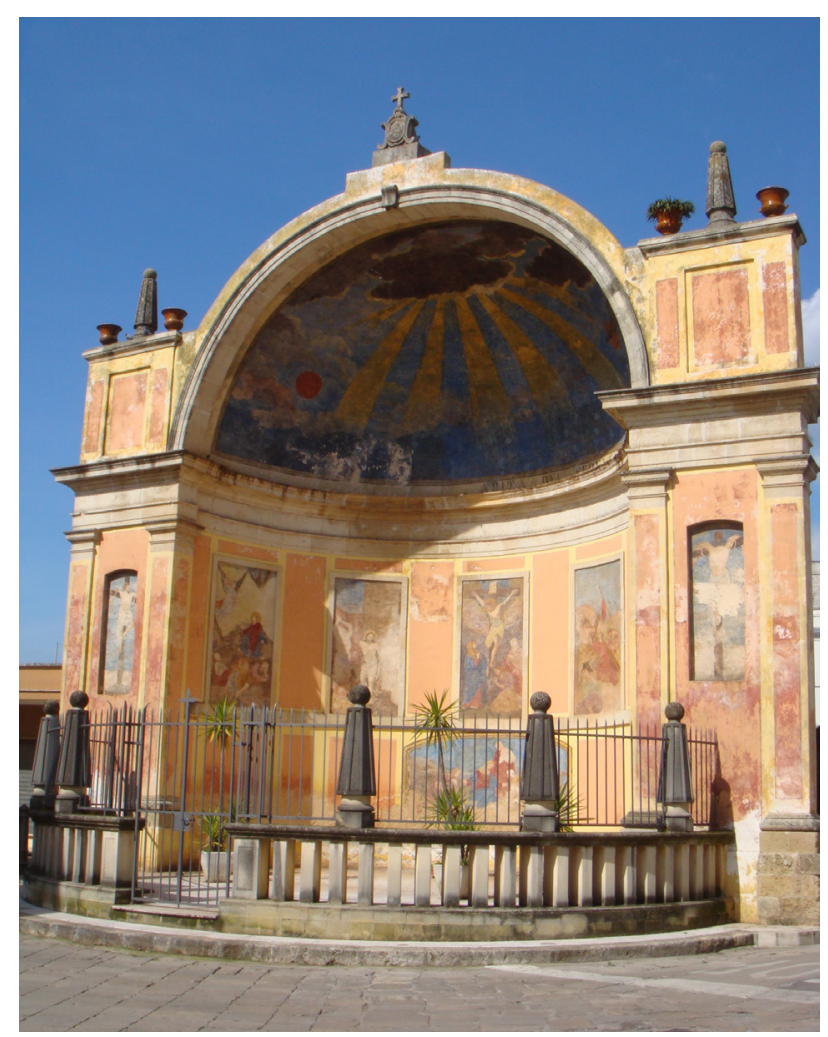


Fig. 2. Diagramma riassuntivo: analisi grafica delle tipologie e loro alterazioni.

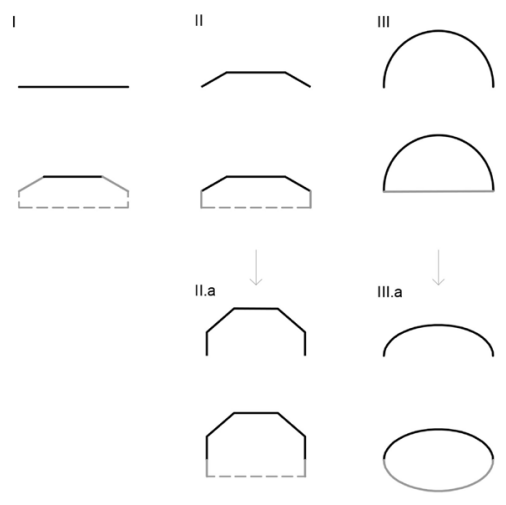

Esempi analoghi di architettura sacra sono numerosi nelle aree nord-occidentali della Francia, Bretagna e Belgio, realizzati tra il XVI e il XVIII secolo. Ad essi coevi, ma in minor numero, sono quelli italiani dell'area lombardo-piemontese. Numerosi sono invece quelli pugliesi, con una particolare concentrazione nelle provincie di Lecce, Brindisi eTaranto. Dalle esigue fonti bibliografiche si desume che i calvari salentini sono stati tutti edificati tra gli ultimi decenni dell'Ottocento e i primi del Novecento; e che si deve la loro realizzazione alla presenza sul territorio degli ordini mendicanti dei gesuiti e dei passionisti, ed in alcuni casi al volere di singoli cittadini. I calvari salentini si contraddistinguono per essere molto differenti, per forma e dimensione, da tutti i manufatti analoghi realizzati in precedenza; questa ragione ha indotto ad una indagine che ha come obiettivo la loro codificazione geometrico/formale (fig. I).

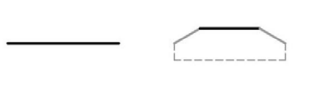

1.1

1.2

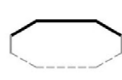

11.2
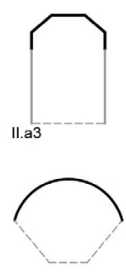

111.3

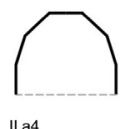

II. $a 4$

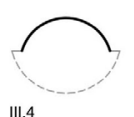

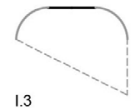

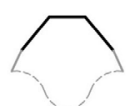

II. 3
11.5

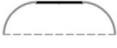

।.5

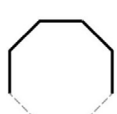

II.a1

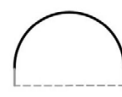

III. 1

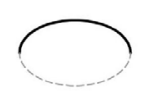

III.a2

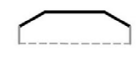

I.1

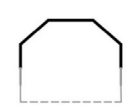

II.a2

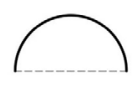

III. 2

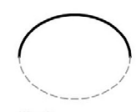

III.a3

\section{Analisi grafica}

A seguito delle diverse campagne di rilievo, che si sono condotte al fine di realizzare un archivio documentale dei calvari salentini, si è avviata una attività di studio analitico/comparativo di questi manufatti concentrandosi in un primo momento sul loro valore e ruolo urbano [Rossi, Castagnolo, Sisci 20 19], per poi procedere ad una analisi tipologico/formale. Già nella prima fase era emersa l'eterogeneità degli esiti derivanti dalla relazione tra contesto e forma, dato rafforzato poi delle analisi grafiche condotte su di un cospicuo numero di casi studio. Tra le principali caratteristiche architettoniche dei calvari salentini vi è l'eclettismo. Realizzati infatti nel periodo in cui la disinvoltura nel mescolare diversi stili architettonici era la norma, queste piccole macchine teatrali che fanno da sfondo ai percorsi urbani dei riti religiosi, 
costituiscono un gruppo a se stante di modelli in cui è stato possibile riconoscere differenti connotati architettonici cui si coniugano eterogenee matrici geometrico/formali.

II posizionamento rispetto ad altri manufatti divide in due macro-gruppi la categoria dei calvari salentini. Al primo appartengono quelli realizzati in aderenza o in prossimità di edifici civili e/o religiosi ed è facile intuire come la matrice geometrica, a cui ogni struttura dei calvari fa riferimento, si alteri quando collocata in spazi di risulta del tessuto urbano; e come invece la geometria latente rimanga inalterata nel caso in cui il calvario è realizzato in un spazi privi di condizionamenti. Questo secondo macro-gruppo in cui la matrice geometrica si conserva integra è quello su cui si è scelto di condurre l'analisi grafica.

Cercando di costruire un metodo di lettura e comprensione dei dati grafici ottenuti a seguito del rilievo si è partiti dell'esaminare e comparare la conformazione planimetrica e lo sviluppo in alzato di ogni singolo manufatto. La variazione dimensionale può essere significativa, infatti si passa da dimensioni minime di $8 \mathrm{~m}$ di larghezza per 3,5 m di altezza, a dimensioni massime di II m per $8 \mathrm{~m}$.

Riconoscendo una possibile analogia tra i calvari e le strutture teatrali, essendo entrambi luoghi di una rappresentazione, si sono assimilati gli elementi architettonici costituenti i piccoli manufatti religiosi a quelli di uno spazio scenico (fig. 2).

Sono stati individuati nella conformazione della scena dei calvari tre distinte parti: il fondale su cui, o davanti cui, è posto il crocifisso; un palcoscenico, antistante il fondale e definito da quinte, le cui dimensioni e profondità possono variare, e può contenere o meno un altare o la riproduzione del monte Calvario in miniatura; un proscenio, in primo piano, che può essere delimitato da una recinzione ma che in ogni caso separa dallo spazio urbano, della platea, quello scenico della rappresentazione.

Generalmente i calvari non condizionati da preesistenze che ne limitano il loro sviluppo compositivo, rispettano una logica di simmetria, ne consegue che il fondale, il crocifisso, il monte Calvario e/o l'altare si dispongano lungo il suo asse. Questa condizione contribuisce a definire le differenti matrici geometriche alla base della conformazione di queste piccole strutture sceniche, che possono essere a sviluppo: lineare (fig. 3, I), poligonale (fig. 3, II), e
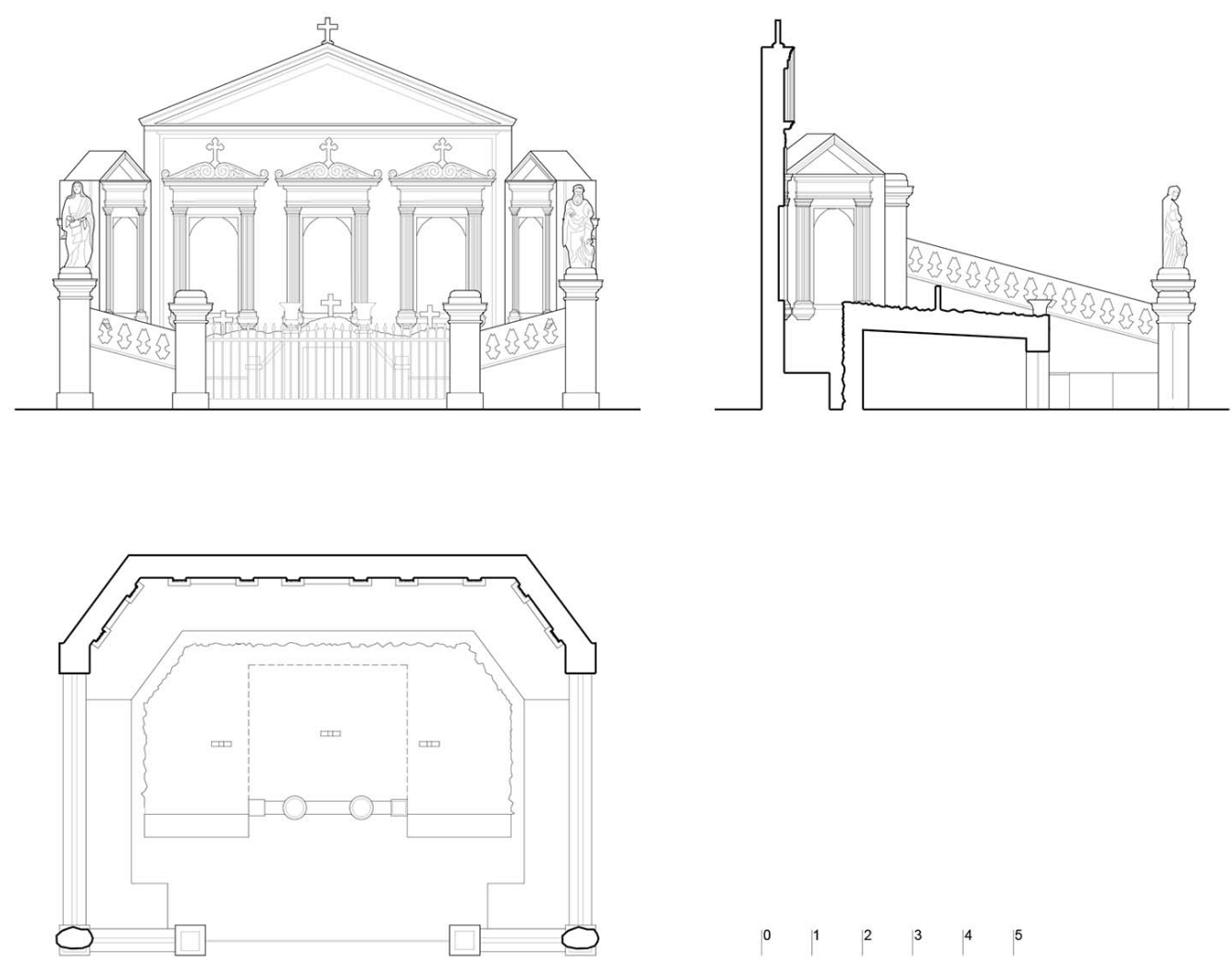
curvilineo (fig. 3, III). Dalle ultime due conformazioni se ne generano ulteriori più articolate e complesse quali soluzioni poligonali con un numero di lati superiore a tre (fig. 3, Il.a) o soluzioni curvilinee che da semicircolari diventano ellittiche o policentriche (fig. 3, III.a).

A partire da questa classificazione per categorie si propone una schematizzazione dei calvari in esame utilizzando una convenzione grafica che ripartisce in tre differenti segni la loro rappresentazione sintetica: linea nera per individuare il fondale della scena; linea grigia per le quinte che delimitano lo spazio scenico; linea grigia tratteggiata per delimitare il proscenio e separarlo dalla platea.

La diversa disposizione e relazione tra queste tre parti individua una casistica riassunta nella tassonomia che segue. La categoria dei calvari con matrice lineare sono quelli di Mesagne, Carovigno, Caprarica, Lequile e Surbo (nell'ordine fig. 4 - schemi I. I, I.2, I.3, I.4 e I.5); i calvari con matrice poligonale a tre lati quelli di Corsano, Leverano, San Cesario, Sternatia e San Vito dei Normanni (nell'ordine fig. 4 - schemi II. I, II.2, II.3, II.4 e II.5); i calvari con matrice poligonale con più di tre lati quelli di Ceglie Messapica, Erchie, Ostuni, Villa Castelli, Tuglie e Zollino (nell'ordine fig.4 - schemi II.al, Il.a2, Il.a3, II.a4, II.a5 e Il.a6); i calvari con matrice circolare quelli di Seclì, San Marzano, San Pancrazio, Francavilla Fontana e Vernole (nell'ordine fig.4 - schemi III. I, III.2, III.3, III.4 e III.5); infine i calvari con matrice geometrica ellittica quelli di Calimera, Melpignano e Monteroni (nell'ordine fig. 4 - schemi III.al, III.a2 e III.a3).

Dall'analisi dello schema tassonomico si evidenzia che le configurazioni dei calvari salentini in buona parte sono condizionate dall'uso delle quinte laterali che regolano la profondità dello spazio scenico. II ruolo che queste assumono consente di raccordare architettonicamente il fondale con il proscenio, spesso risolto con quote ed altezze differenti, e da un punto di vista scenografico di collaborare alla definizione dello spazio in cui si svolge il rituale religioso della crocefissione e deposizione del corpo di Cristo.

Conclude la spazio scenico, oltre le quinte, il proscenio che assume le fattezze di un sagrato separando lo spazio sacro da quello profano e contribuisce alla definizione dello spazio fisico del calvario concludendo o integrando la matrice geometrica sottesa, comunque nel rispetto della simmetria assiale.
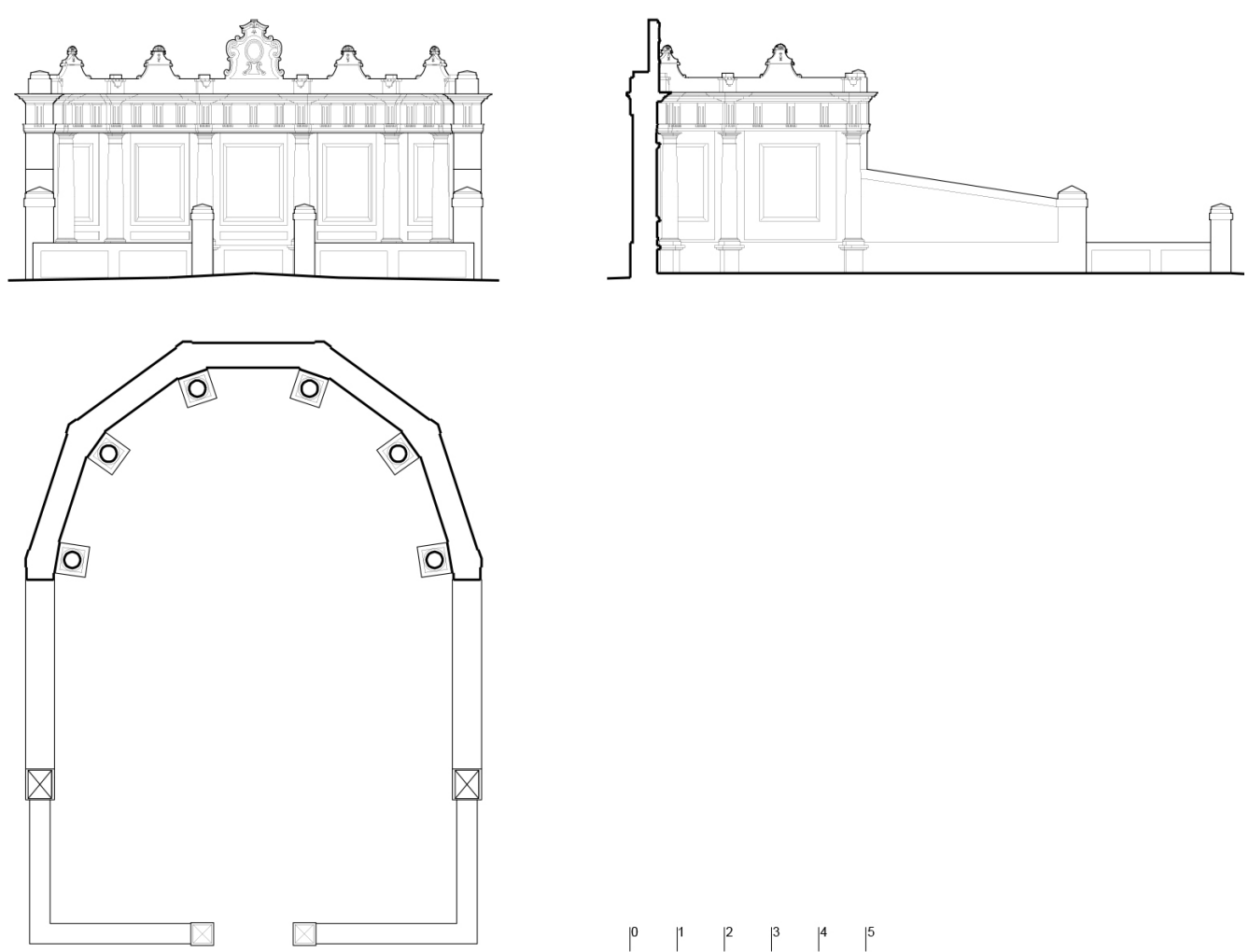


\section{Casi studio}

I tre casi studio sono stati scelti in funzione della dimensione complessiva tra di loro prossima, in modo da facilitare il paragone; e delle caratteristiche geometriche, owero selezionando il caso che meglio poteva restituire la visione della matrice.

II calvario di Carovigno (fig. 5, fig. 4 schema I.2) presenta una matrice geometrica di tipo lineare, desunta dalla lettura dei suoi disegni descrittivi in cui è evidente, soprattutto in elevato, la presenza di un fondale netto e definito dalla partitura architettonica con timpano. Questo risulta indipendente dalle quinte inclinate poste ai lati, che svolgono un ruolo secondario. In asse al fondale scandito da tre specchiature con lesene e timpano, si trova una stilizzazione del monte calvario sormontato dal crocefisso, che occupa la zona del palcoscenico in parte raccolto nello spazio individuato dall'inclinazione delle quinte sceniche che proseguono sui lati il motivo architettonico a specchiature. A raccordare le quinte e definire il proscenio oltre il monte Calvario vi è una recinzione progressivamente sempre più bassa e sui cui spigoli sono collocate due statue. II recinto si conclude con un cancello che lascia intravedere dall'esterno l'incavo nella miniatura del monte Calvario in cui vengono deposti doni votivi. II calvario di Erchie (fig. 6, fig.4 schema Il.a2) presenta una matrice geometrica di tipo poligonale, nella variante di cinque lati. Dalla lettura dei disegni descrittivi si evince una corrispondenza tra lo sviluppo planimetrico e quello in elevato. In questo caso il fondale è l'intero elemento poligonale scandito dall'ordine architettonico sormontato da trabeazione, con architrave e fregio, le cui colonne avanzano distaccandosi dal piano retrostante ed inquadrano cinque specchiature. Al di sopra della trabeazione la cornice si articola per tutta la lunghezza con una alternanza di elementi composti da volute e conchiglie, posti in asse alle colonne. Rispetto al caso precedente avviene un processo di ripiegamento del fondale ed annessione delle quinte che restano qui individuate solo da due bassi muretti inclinati che proseguono fino ad intercettare il recinto del proscenio, il cui passaggio è individuato da due bassi pilastri. In ultimo il calvario di Melpignano (fig. 7, fig. 4 schema III.a2) appartiene alla matrice curvilinea di tipo ellittico. Come nel precedente caso il fondale è individuato dalla matrice geometrica stessa tanto in pianta quanto in elevato. La variazione consiste nella trasformazione dell'andamento da linea spezzata a semiellittica e, soprattutto, nella fusione definitiva di fondale e quinte che rende in elevato l'andamento discendente verso le estremità, come
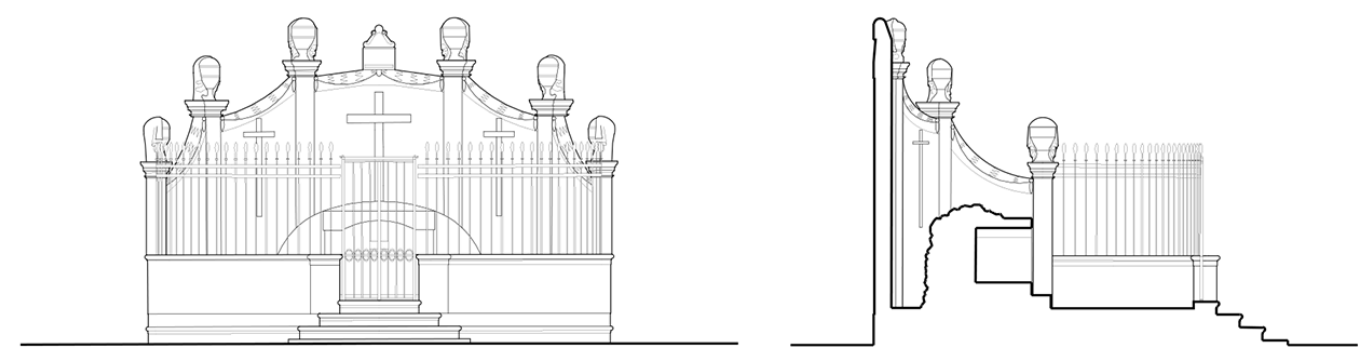

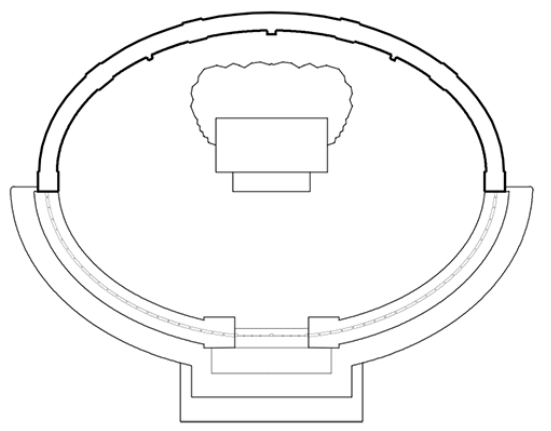


a cercare un raccordo fluido con la recinzione del proscenio e il fondale stesso. Questo è scandito da sei pilastri, che inquadrano tre croci lignee, sormontati da vasi in pietra leccese riportanti l'iconografia della Passione di Cristo. In corrispondenza con l'asse centrale ma in posizione arretrata, rispetto al centro geometrico, vi è una miniatura del monte Calvario nella cui nicchia è conservato un gruppo scultoreo della deposizione del Cristo. Il proscenio si definisce qui come perfetta simmetria del fondale. II basso muretto sormontato da una ringhiera in ferro è semiellittico e preceduto da quattro gradini.

\section{Conclusione}

Nel processo di documentazione e analisi descritto - che parte dal rilevamento dei manufatti per proseguire nella loro restituzione grafica e si conclude nello studio ed osservazione degli elaborati prodotti, facendo ricorso a criteri di indagine che agiscono per scomposizione in elementi minimi costitutivi - è possibile individuare una metodologia in grado di portare ad un unico grado di astrazione e quindi di osservazione oggetti che nell'apparenza sembrano essere differenti tra loro. Le matrici geometriche estrapolate sono state poi utilizzate per generare un'immagine (fig. 2) che fosse in grado di rendere rapidamente visibile tanto la varietà delle declinazioni delle tre matrici, quanto il loro persistere in forma latente in ognuno dei calvari presi in esame. La scelta di condurre questo studio sui calvari salentini non è stata dunque dettata da una semplice contingenza, ma da una particolare coincidenza che vede in queste architetture il concentrarsi di diversi fattori, tra cui l'elevata concentrazione in un'area geografica di modeste dimensioni, la molteplicità delle declinazioni formali che li rende tutti apparentemente distanti tra loro, e non ultimo l'essere oggetti in cui persiste la memoria di una gesto rituale profondamente radicato sul territorio.

\section{Riferimenti bibliografici}

Aurisicchio Enza (2003). Le edicole votive di Ostuni. Progetto Regione Puglia. Assessorato Pubblica Istruzione C.R.S.E.C. BR/20

De Zedelgem Amédée (2004). Historical essay on the devotion to the Via Crucis. Ponzano-Casale Monferrato: ATLAS.

Di Napoli Giuseppe (2004). Disegnare e conoscere. Milano: Enaudi.

Mellone, Lucia (2009). I Calvari della provincia di Lecce: architettura e devozione. Tesi di Laurea in Storia dell'architettura Moderna e Contemporanea, Università del Salento, relatore prof.Vincenzo Cazzato.

Morleo Cosimo Vincenzo (1993). Erchie dalle origini ad oggi. Oria: Italgrafica.

Palmisano Francesca (20l0). Dai sacri monti ai Calvari: architettura e devozione nelle provincie di Taranto e Brindisi. Tesi di Laurea in Storia dell'architettura Moderna e Contemporanea, Università del Salento, relatore prof.Vincenzo Cazzato.

Perretti Bruno (20I I). Calvari. Architettura della pietà popolare nell'area lonico-Salentina. Manduria: Barbieri Selvaggi

Rizzato Pancrazio (2005). Arte sacra in Erchie: itinerario tra i beni artistici delle chiese e dintorni con cenni storici e riferimenti a riti e tradizioni locali. Brindisi:Tipografia Minigraf.

Rossi Gabriele, Castagnolo Valentina, Sisci Francesca (2019). Architecture and popular devotion. The double-code for the enhancement of the Salento calvaries. In Conte Antonio, Guida Antonella (a cura di). ReUSO Matera. Patrimonio in divenire. Conoscere valorizzare abitare. VII Convegno Internazionale sulla documentazione, conservazione e recupero del patrimonio architettonico e sulla tutela paesaggistica. Matera 23-26 ottobre 20 19. Roma: Gangemi Editore, pp. I063- 1076.

\section{Autori}

Gabriele Rossi, Politecnico di Bari, gabrielerossi@poliba.it

Francesca Sisci, Politecnico di Bari, francesca_sisci@icloud.com

Per citare questo capitolo: Rossi Gabriele, Sisci Francesca (2020). I calvari salentini. Analisi grafica e documentazione/The Salento's Calvaries. Graphical analysis and documentation. In Arena A., Arena M., Brandolino R.G., Colistra D., Ginex G., Mediati D., Nucifora S., Raffa P. (a cura di). Connettere. Un disegno per annodare e tessere. Atti del $42^{\circ}$ Convegno Internazionale dei Docenti delle Discipline della Rappresentazione/Connecting. Drawing for weaving relationships. Proceedings of the 42 th International Conference of Representation Disciplines Teachers. Milano: FrancoAngeli. pp. $|4| \mid-1424$. 


\title{
The Salento's Calvaries. Graphical Analysis and Documentation
}

\author{
Gabriele Rossi \\ Francesca Sisci
}

\section{Abstract}

The devotional calvaries are part of the so-called minor architecture typology. Salento, a southern area of Puglia, was especially interested by such phenomenon within a period between the XIX and the early $X X$ century. The promoters and financers of these works were begging classes and private citizens, who did so would provide their land a 'copy' of the Sacred Mount Calvary: the peak of the Via Crucis and the Pilgrims' journey to the Holy Land. The interest in these works comes on the one hand because they are an expression of the religious memory of a community, and on the another hand for their typological heterogeneity. The study carried out had the aim of defining a possible formal classification of the calvaries. To reach this, the instruments of Architectural Drawing and Survey were used, allowing the graphic analysis process. From the experience of the Survey and Drawing activities, an analytic study of the artifacts was made, leading to the possibility of classifying them in macro-categories and identifying the formal variations for each category.

This essay presents three case studies: Carovigno, Erchie, and Melpignano. Each one refers to one of the three macro-categories identified, not only presenting features useful to a formal reading but also contemplating the ideal case and its transformation in an architectonical object.

Keywords

calvaries, documentation, survey, graphic analysis, Salento.

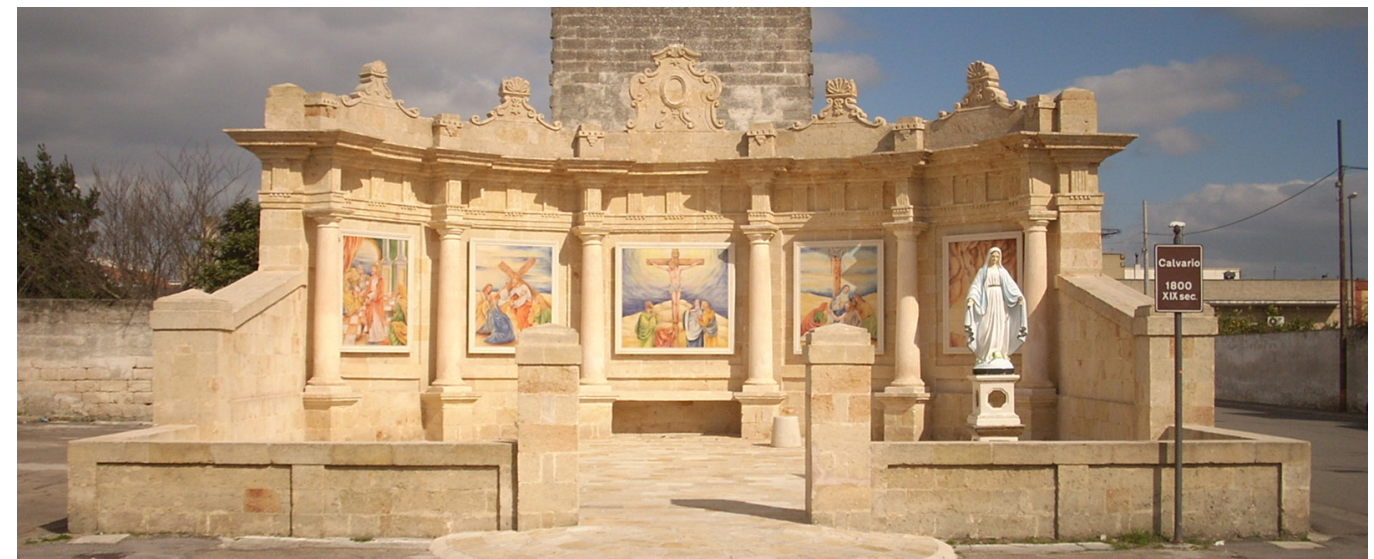




\section{Introduction}

The devotional practice of pilgrimage in the Holy Ground spreads out since the first centuries of the Christian age. It's well documented in the diaries of the medieval travelers. They tell about the stages of the path followed toward the places where Jesus lived and died [Alliata, Bottini, Kaswalder et al. 2009]. In 3 I 3 A.D. Emperor Constantin gave the Christians complete freedom of worship, with the Editto di Milano, spreading the pilgrimage habit. He even encouraged it by building the Church of the Holy Sepulchre. Since then, this practice has been uninterrupted. In fact, even if the navigation between the East and the West became difficult between the VII and X century -because of the Muslim conquests in the Balkan areas- the slow-down of the pilgrimage led to the local creation of a series of Sanctuaries aiming to repurpose what the pilgrims would have found in the Holy Ground [Perretti $20 \mathrm{II}$ ]. The same happened during the crusade expeditions (late XI to half XIII century) when the spreading of sanctuaries replicating the Holy Places such as Homes of Nazareth, Holy Mounts or Jerusalem, anticipated the modern devotion of the Via Crucis. The outcome of this practice, born from the need of safeguarding the travelers' safety, contributed to transferring the sense of pilgrimage from the physical to the spiritual meaning. The category of the Holy Places includes the calvaries. They were born and started spreading after the Concilio di Trento (I545- I563), which imposed a review of the Passio Christi and the constitution of the itinerarium fidei. In this way they aiming to guarantee to all devotees the spiritual gifts given to the first medieval pilgrims.

The word Calvary comes from the Latin calvarium, which in Aramaic language means cranium (gulgulta), the hill out of the Jerusalem walls where Jesus was crucified, according to the Sacred Writings. For this reason, calvaries represent paradigmatic episodes of popular worship that want to transpose the pilgrimage experience in Holy Ground into the processional path of the Via Crucis that goes through the urban areas culminating in the calvary.

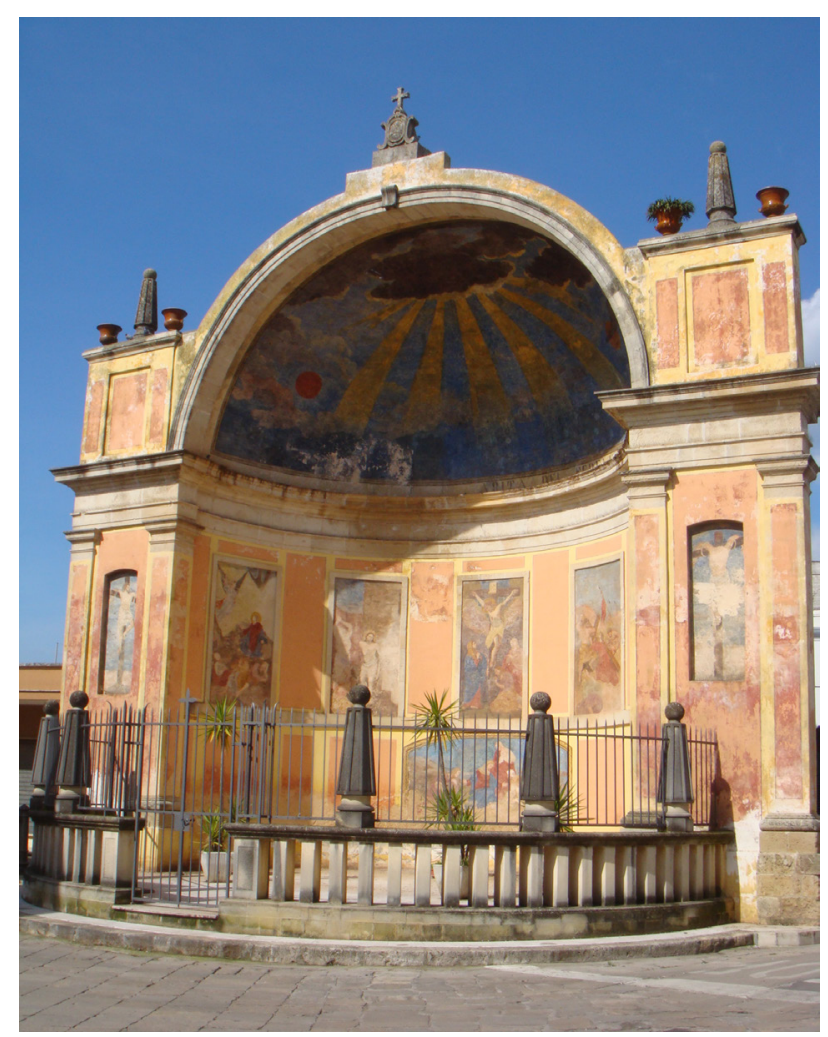


Fig. 2. Summary diagram: graphic analysis of typologies and their alterations.

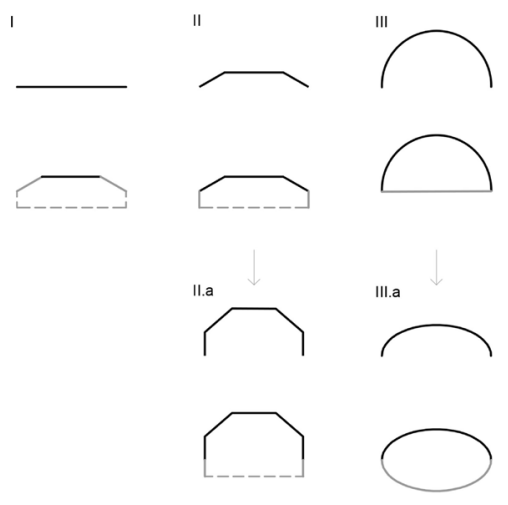

There are many similar examples of sacred architecture in the north-western areas of France, Brittany and Belgium, made between the XVI and XVIII century. Less were made in the same period in the Italian area of Lombardy-Piedmont, while many are found in Puglia, particularly concentrated in the territory of Lecce, Brindisi and Taranto.

The narrow bibliographic sources reveal that the calvaries of Salento were all built between the last decades of the XIX and early XX century. Their creation was thanks to the mendicant orders of Jesuits and Passionists present locally, and in some cases thanks to the wish of singular citizens. The calvaries of Salento are distinguishing different form all the other works made previously, for their shapes and sizes. This reason led to conduct a survey whose goal is their geometrical and formal classification (fig. I).

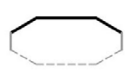

11.2
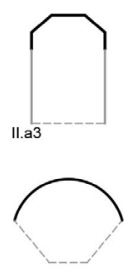

111.3
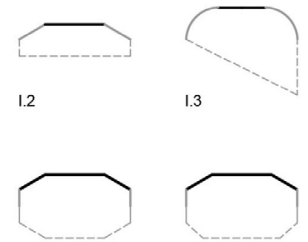

II. 3

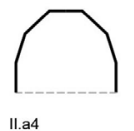

II. 44

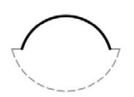

III. 4
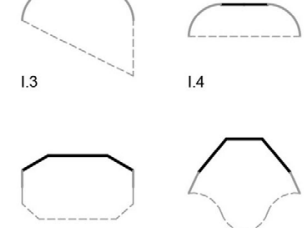

II. 4

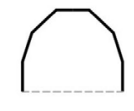

II.a5

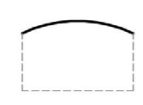

III.5

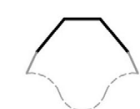

II.5
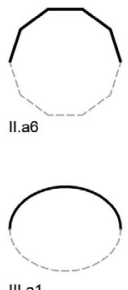

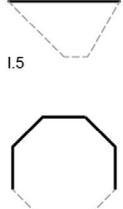

II.a1

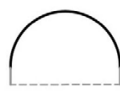

III.1

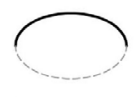

III.a2

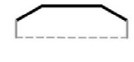

II.1

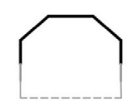

II.a2

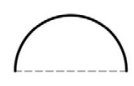

III.2

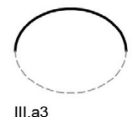

\section{Graphic analysis}

To create a documentary archive of Salento's calvaries, the multiple sessions of the survey were followed by analytical and comparative study activity. This was initially concentrated on their value and their urban role [Rossi, Castagnolo, Sisci 2019], then it continued to typological and formal analysis. The heterogeneity of the results from the relationship between context and form arose already during the first phase; this fact was consolidated with the following graphic analyses conducted on a substantial number of case studies.

One of the main architectural features of Salento's calvaries is the eclecticism. In fact, they were built when different architectural theories were easily mixed. Like 'theatrical machines', they are the background of the urban paths of religious rituals. The calvaries constitute an in- 
dependent group of models in which is possible to identify different architecture characters, combined with heterogeneous geometric and formal matrixes.

Salento's calvaries are divided into two macro-groups by their arrangement toward the other artifacts. The first one consists of those built nearby or attached to civil and/or religious constructions. In this case, the basic geometric matrix of calvaries category is altered as they are placed in spaces sized by the urban configuration. Differently, the calvaries of the second group present the basic geometric matrix intact as they are built on spaces with no influences. The graphical analysis has been conducted on second group.

Aiming to build a method of reading and comprehension of the graphical data achieved with the survey, we started examining and comparing the planimetric structure and the elevation of each single calvary. They can vary significantly in size they go from minimum dimensions of $8 \mathrm{~m}$ wide by $3.5 \mathrm{~m}$ high, to maximum dimensions of $11 \mathrm{~m}$ by $8 \mathrm{~m}$.

A possible analogy was recognized between calvaries and theatrical structures, being them both locations of a representation. The architecture elements constituting the small religious artifact were assimilated to those of a theatrical space (fig. 2).

Three different parts of the calvaries structure were identified: the 'backdrop' on which, or before which, the crucifix is placed; the stage in front of the backdrop and its scenery sets, which size and depth can vary, potentially hosting an altar and a miniature reproduction of the Mount Calvary; a proscenium in the foreground, sometimes delimited by a fence, separating the stalls (urban space) from the scenic stage of the representation.

Generally, the calvaries not conditioned by pre-existing constructions which limit their development, follow a logic of symmetry. Therefore the backdrop, the crucifix, the Mount Calvary and/or the altar are arranged on its axis. This condition contributes to defining the different geometric matrixes which are the base of the conformation of these small scenic structures. Their development can be: linear (fig. 3, I), polygonal (fig. 3, II), and curvilinear (fig. 3 , III). The last two development generated further ones, more articulated and complex like polygonal solutions with more than there sides (fig. 3, II a) or semi-circular solutions which becoming elliptical or polycentric (fig. 3, III a).
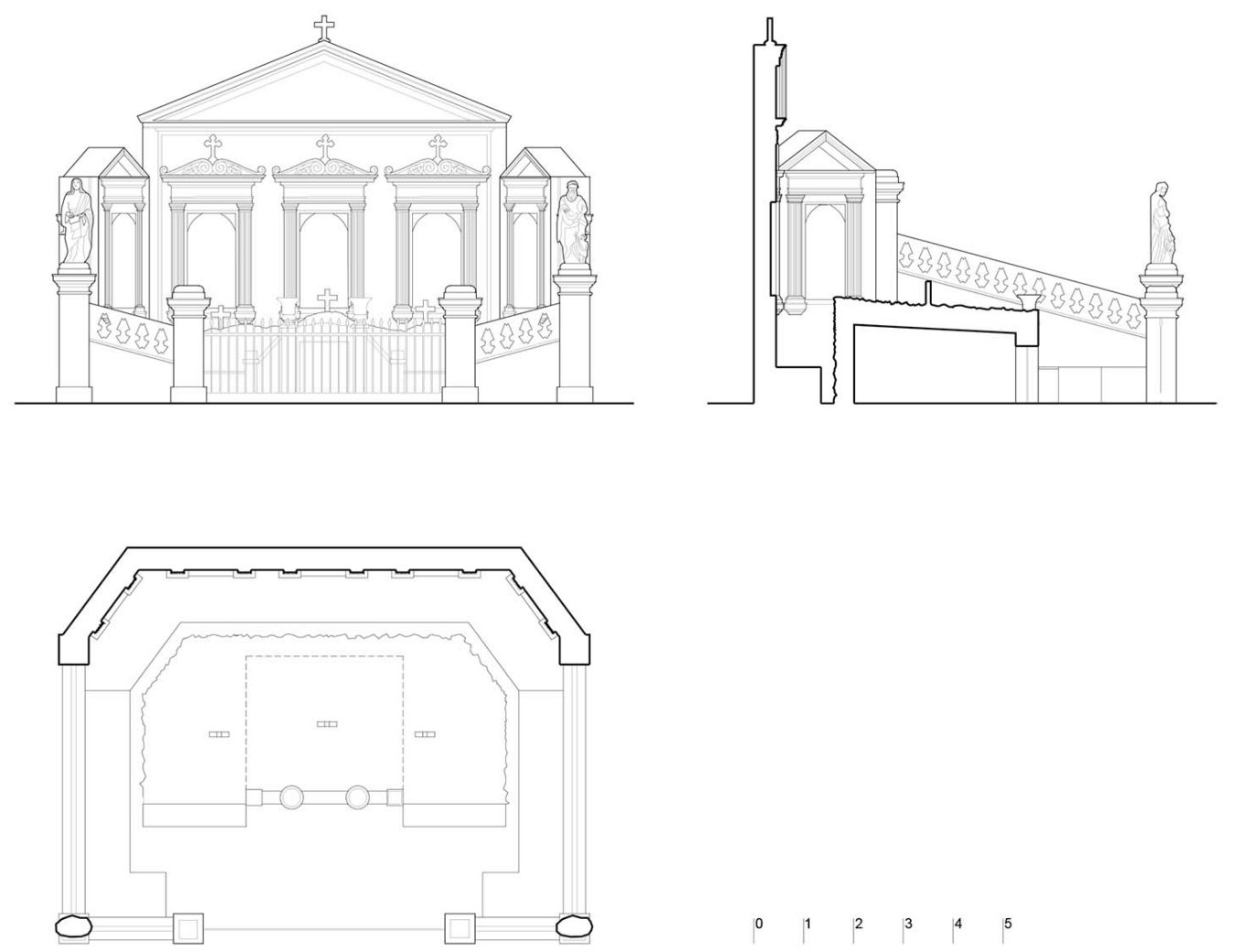
Starting from this classification we propose a diagram of the examined calvaries. The synthetic graphic convention represents through three different signs their component parts: black line to indicate the backdrop of the stage; grey line for the scenic wings delimiting the stage; grey dashed line to indicate the apron, separating it from the stalls.

The diverse arrangement and relationship between these three parts identifies records recapped in the following taxonomy. The category of calvaries with linear matrix includes Mesagne, Carovigno, Caprarica, Lequile and Surbo (in this order fig. 4 - schemes I. I, I.2, I.3, I.4, I.5); the calvaries with three-sides polygonal matrix are Corsano, Leverano, San Cesario, Sternatia and San Vito dei Normanni (in this order fig. 4 - schemes II. I, II.2, II.3, II.4, II.5); the calvaries with a polygonal matrix with more than three sides are Ceglie Messapica, Erchie, Ostuni, Villa Castelli, Tuglie e Zollino (in this order fig. 4 - schemes Il.al, Il.a2, II.a3, II.a4, II.a5, II.a6); the calvaries with circular matrix are Seclì, San Marzano, San Pancrazio, Francavilla Fontana and Vernole (in this order fig. 4 - schemes III. I, III.2, III.3, III.4, III.5); lastly, the calvaries with elliptical matrix are Calimera, Melpignano and Montenori (in this order fig. 4 - schemes III.al, III.a2, III.a3).

The taxonomic scheme highlights that the configurations of the Salento's calvaries are largely conditioned by the usage of scenic wings that regulate the depth of the stage. They in fact assume a role that architecturally allows to link the backdrop with the apron, often on different heights. From a scenic point of view they also help defining the space in which the religious ritual of crucifixion and deposition of Jesus takes place.

The apron completes the stage, acquiring the features of a parvis: to separate the sacred space form the profane one. Furthermore contribute to defining the physical space of the calvary, concluding or integrating the subtended geometric matrix, anyway on the symmetrical axis.
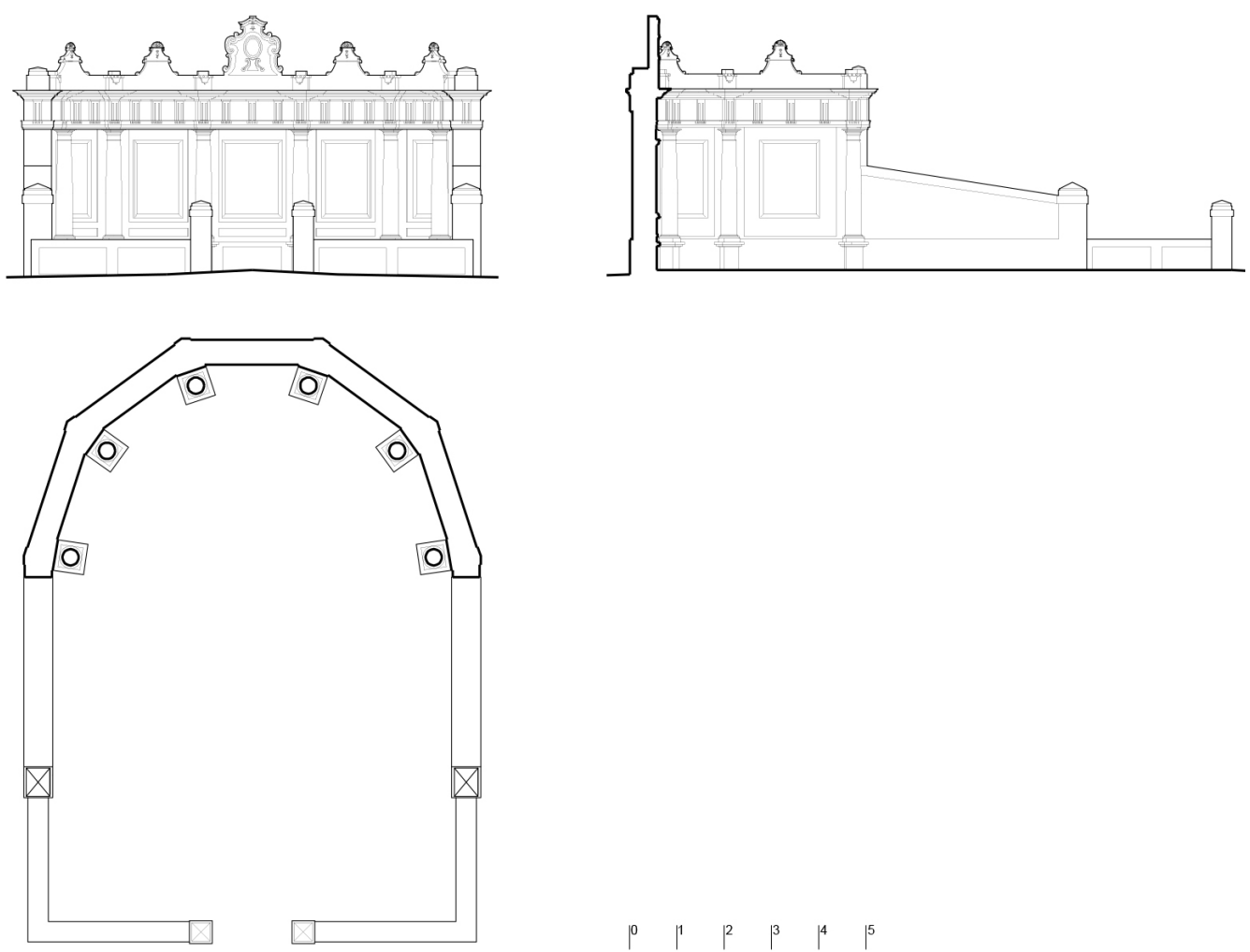


\section{Case Studies}

The three case studies have been chosen based of two criteria. The first is the similar overall size, to facilitate the comparison; and the second is the basic geometric matrix, choosing the cases that could best show it.

The calvary of Carovigno (fig. 5, fig. 4 scheme I.2) is shaped on the linear geometric matrix. Observing its drawings, mainly the elevation, it's possible to notice a clear backdrop defined by the architectural configuration with tympanum. The linear backdrop result independent from the lateral scenic wings, which have a secondary role. On the same axis of the backdrop- which is divided by three panels with pilasters and tympanum -there is a stylisation of the Mount Calvary surmounted by the crucifix. It occupies the stage area which is partially defined by the tilted scenic wings that keep repeating the panel sequence on the sides. A progressively lowering fencing links the stage whit the apron and defines the area beyond the Mount Calvary.Two statues are placed on its corners. The fence is concluded with a gate that from the outside allows to half-see the hollow in the Mount Calvary miniature, where votive gifts are put down.

The calvary of Erchie (fig. 6, fig. 4 scheme Il.a2) is shaped on the polygonal geometric matrix, using the 5-sides variant. Its drawings show a correspondence between the diagram and the elevation. In this case the backdrop is the whole polygonal element, marked by the architectural order, surmounted by the entablature, with architrave and frieze, which columns are detached from the wall behind and define five panels. The cornice above the continuous entablature to the whole length, alternating elements made of volute and shells, placed in the columns' axis. Compared to the previous case, there is a process of folding of the backdrop and annexation of the stage, which are here defined only by two angled low walls that continue until the apron fencing, which passage is defined by two low pillars.

Lastly, the calvary of Melpignano (fig. 7, fig. 4 scheme III.a2) belongs to the elliptical type of the curvilinear geometric matrix. Like in the previous case, the backdrop is defined by the geometric matrix itself, both in the diagram and the elevation. The variation consists in the transformation of the path from polygonal chain to a semi-elliptical line, and mostly in the definitive fusion of backdrop and scenic wings. The descendent flowing of elevation going towards the extremities, trying to smoothly link the apron fencing and the backdrop itself.
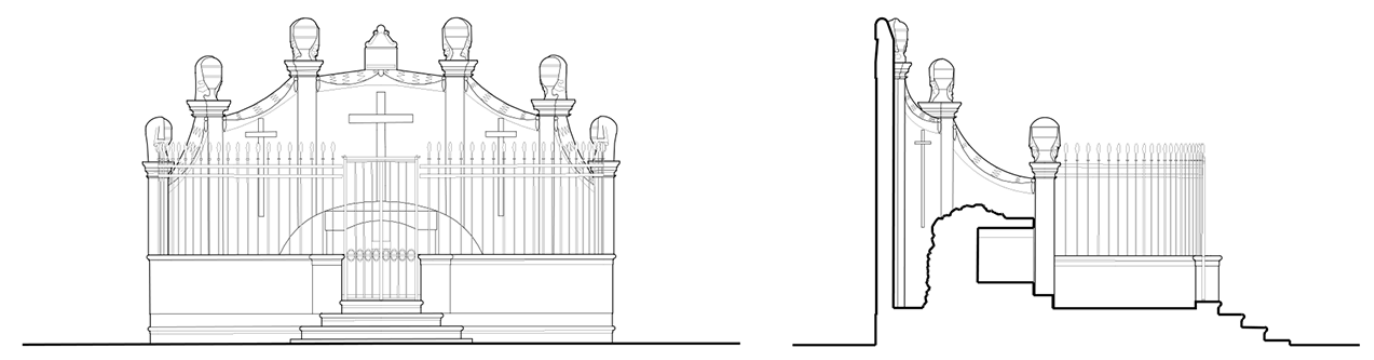

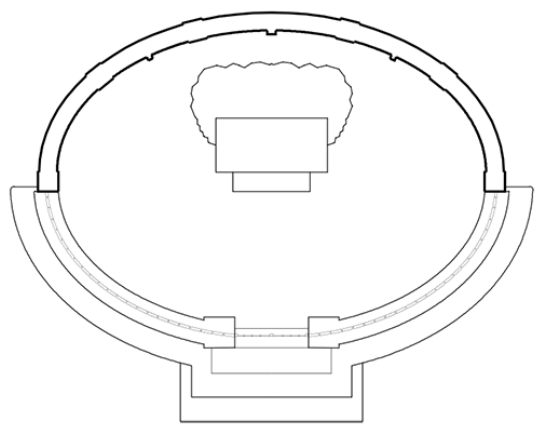


All this is marked by six pillars, framing three wooden crosses, surmounted by vases made of Lecce stone with the iconography of Jesus's passion. A miniature of Mount Calvary, in which a niche conserve a sculpture of the deposition of Jesus, is placed coinciding with the central axis, set-back positioned. The apron is here defined as the perfect symmetry of the backdrop. Four steps precede the low, semi-elliptical wall surmounted by an iron fencing.

\section{Conclusion}

The described process of documentation and analysis, start from the survey of the calvaries to their graphic representations and concluding into their observation study. The research is conducted by survey criteria that operate a breakdown to the minimal constituting elements. In this way is possible to define a methodology able to find a single way to observe objects that looks different. The deducted geometric matrixes have been used to generate an image (fig. 2) capable of quickly show the multiple varieties of the three matrixes and their latent persistence in each of the examined calvaries.

The choice of conducting this study on the Salento's calvaries was therefore not just circumstantial, but imposed by a particular coincidence: the concentration of different factors, like the high concentration in a small geographical area, the multiplicity of the formal versions that only apparently makes each calvary different, and the fact that they preserve the memory of a ritual deeply-rooted in the territory.

\section{References}

Aurisicchio Enza (2003). Le edicole votive di Ostuni. Progetto Regione Puglia. Assessorato Pubblica Istruzione C.R.S.E.C. BR/20

De Zedelgem Amédée (2004). Historical essay on the devotion to the Via Crucis. Ponzano-Casale Monferrato: ATLAS.

Di Napoli Giuseppe (2004). Disegnare e conoscere. Milano: Enaudi.

Mellone, Lucia (2009). I Calvari della provincia di Lecce: architettura e devozione. Tesi di Laurea in Storia dell'architettura Moderna e Contemporanea, Università del Salento, relatore prof.Vincenzo Cazzato.

Morleo Cosimo Vincenzo (1993). Erchie dalle origini ad oggi. Oria: Italgrafica.

Palmisano Francesca (20 I0). Dai sacri monti ai Calvari: architettura e devozione nelle provincie di Taranto e Brindisi. Tesi di Laurea in Storia dell'architettura Moderna e Contemporanea, Università del Salento, relatore prof.Vincenzo Cazzato.

Perretti Bruno (20I I). Calvari. Architettura della pietà popolare nell'area lonico-Salentina. Manduria: Barbieri Selvagg

Rizzato Pancrazio (2005). Arte sacra in Erchie: itinerario tra i beni artistici delle chiese e dintorni con cenni storici e riferimenti a riti e tradizioni locali. Brindisi:Tipografia Minigraf.

Rossi Gabriele, Castagnolo Valentina, Sisci Francesca (2019). Architecture and popular devotion. The double-code for the enhancement of the Salento calvaries. In Conte Antonio, Guida Antonella (a cura di). ReUSO Matera. Patrimonio in divenire. Conoscere valorizzare abitare. VII Convegno Internazionale sulla documentazione, conservazione e recupero del patrimonio architettonico e sulla tutela paesaggistica. Matera 23-26 ottobre 20 I 9. Roma: Gangemi Editore, pp. I063- 1076.

\footnotetext{
Authors

Gabriele Rossi, Politecnico di Bari, gabrielerossi@poliba.it

Francesca Sisci, Politecnico di Bari, francesca_sisci@icloud.com
}

To cite this chapter. Rossi Gabriele, Sisci Francesca (2020). I calvari salentini. Analisi grafica e documentazione/The Salento's Calvaries. Graphical analysis and documentation. In Arena A., Arena M., Brandolino R.G., Colistra D., Ginex G., Mediati D., Nucifora S., Raffa P. (a cura di). Connettere. Un disegno per annodare e tessere. Atti del $42^{\circ}$ Convegno Internazionale dei Docenti delle Discipline della Rappresentazione/Connecting. Drawing for weaving relationships. Proceedings of the 42 th International Conference of Representation Disciplines Teachers. Milano: Franco Angeli, pp. I 4 I I - 424. 